MH Egészségügyi Központ Pszichiátriai Osztály

\title{
A pszichológiai reziliencia, mint integrált alkalmazkodó rendszer
}

\author{
Dr. Urbán Nóra pszichológus alezredes, \\ Dr. Kovács László ny. orvos ezredes, $\mathrm{PhD}$
}

Kulcsszavak: pszichológiai reziliencia, pszichotrauma, poszttraumás stresszbetegség (PTSD)

\begin{abstract}
A 2001. szeptember 11-i terrortámadást követően az Amerikai Pszichológiai Társaság által közölt tények, adatok, publikációk egyre inkább a rugalmas ellenállóképesség, azaz a pszichológiai reziliencia szerepére helyezték a hangsúlyt a traumatikus eseményekkel kapcsolatban. A legtöbb egyén rendelkezik olyan képességekkel, amelyek lehetővé teszik a stressz igen magas szintjével való megküzdést is. A pszichológiai reziliencia egy olyan adaptációs folyamat, amelynek segítségével kezelhetővé válik egy nehéz élethelyzet, szerencsétlenség, tragédia, trauma, az egyének hatékonyan képesek megküzdeni a trauma okozta distressz tüneteivel. A reziliencia kutatása nemzetközi szinten mind a gyermekkori és felnőttkori (többszöri) traumatizációkkal, mind a védelmi szektor területén az extrém stresszhelyzetekhez kötődő traumatizálódással összefüggésben, egyaránt erősödik.
\end{abstract}

\section{A pszichológiai reziliencia fogalma}

Napjainkban egyre nagyobb figyelmet kapnak mind civil, mind katonai területen a traumát követő patológiás állapotok, így a poszttraumás stresszbetegség (PTSD) kialakulása és annak megelőzési lehetőségei. Különösen amióta a statisztikai adatok alapján napjainkban a harci bevetéseket követően akár a $20 \%$-ot is meghaladhatja a PTSD előfordulási aránya[1].
A reziliencia fogalma elsőként a fejlődéspszichológia területén tűnt fel, amikor szélsőséges életeseményeknek kitett gyermekek viselkedését tanulmányozták. Később a reziliencia-kutatások egyre inkább kiterjedtek a felnőtt populációkra, részben olyanokra, akik maguk is traumatikus események áldoztaivá váltak, illetve azokra, akik hivatásukból eredően extrém, különleges helyzetek résztvevői, traumatikus események elszenvedői, illetve szemtanúi voltak ( $\mathrm{pl}$. 
emberi szenvedés, halál), így a katonák, a rendőrök és a katasztrófavédelemben résztvevő szervezetek vagy civil mentőalakulatok és segélyszervezetek dolgozói. E különösen veszélyeztetett populációk esetében kiemelkedő jelentőségűvé vált a rugalmas ellenállóképesség protektív szerepe a stressz reakciók és pszichopatológia szempontjából. A reziliencia konstruktuma számos faktort ölel fel, több, mint a személyiség megküzdési kapacitása (coping készsége), mégis úgy tünik, hogy még nincs kialakult, integrált koncepciója.

A reziliencia rugalmas ellenállási képesség, azaz valamely rendszernek, legyen az egy egyén, egy szervezet, egy ökoszisztéma, azon képessége, hogy erőteljes, meg-megújuló, vagy akár sokkszerü külső hatásokhoz sikeresen alkalmazkodjon [2]. A szó gyökere a latin „salire” (ugrani) ige: re-salire annyi, mint hátraugrani, hátrahőkölni, előre-hátra feszülni, de nem eltörni. Ez eredetileg a mérnöki fizikából vett kifejezés, napjainkban szinte járványszerűen terjed. Holling a reziliencia - kutatás egyik vezéralakja, mutatott rá arra a paradoxonra még a 70-es években, amely fennáll egy rendszer teljesítőképessége, teherbíró képessége, állandósága, megmaradása és változásra való képessége között. Az ellentmondásnak megfelelően az ökológiai irodalomban a rezilienciának két eltérő definíciója született. Az első definíció értelmében a reziliencia annak a mértéktartománya, amelyen belül a rendszer megőrzi belső egyensúlyát a ráható erők ellenében. A második meghatározásban átértelmeződik a stabilitás fogalma, a rendszer az őt a korábbi egyensúlyi állapotából kibillentő erőhatásra úgy reagál, hogy rugalmas módon új egyensúlyra tegyen szert. Míg az első definíció egy rendszer hatékonyságára, teherbíró képességére, kiszámíthatóságára összpontosít, addig a második inkább a szívósságra, perzisztenciára, adaptivitási készségre.

Garmezy, Masten, Tellegen [3] megfogalmazásában a reziliencia a gyermek kompetencia megnyilvánulása az öt érő stresszteli események ellenében.

Rutter [4] alapján a stresszel való szembeszegülés, mely lehetővé teszi az önbizalom és a kompetencia növekedését.

Masten [5] szerint a reziliencia egy séma, amely akut vagy krónikus stresszkeltőkkel, krónikus veszélyeztető körülményekkel szembeni sikeres adaptációval jellemezhetö.

Gordon [6] a viszontagságos körülményekkel szemben megnyilvánuló képességnek tartja a rezilienciát, ez segíti a boldogulást, éretté válást és a kompetencia növelését. A nehéz körülmények közötti jó eredmény elérését, pozitív kimenetelt jelent.

A definíciók azonosságai:

- viszontagságos külső környezet,

- az egyén bizonyos belső tulajdonságai, védelmi faktorainak megléte,

- a külső veszélyeztető körülményekkel való hatékony megküzdés,

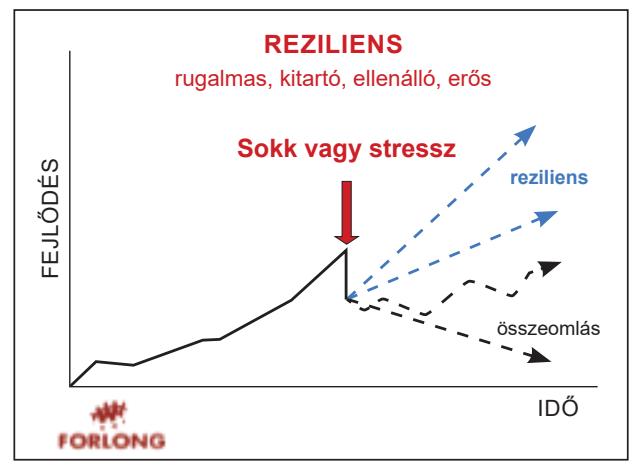

1. ábra. Reziliencia definíciója Forrás: http://www.forlong.hu/blog/2011/08/25/ a-mexikoi-60-at-maig-nem-hevertuk-ki-avagymi-fan-terem-a-reziliencia/ 
- a helyzetekhez való jó alkalmazkodás képessége, az élethelyzetekből való optimális kimenetel.

Rutter álláspontja szerint a rezilienciát nem lehet személyiségvonásként értelmezni, hiszen valaki lehet reziliens egy adott típusú kihívással szemben, míg egy másikkal szemben viszont nem.

A rezilienica sokkal inkább dinamikus folyamatként értelmezhetö, a belső képességek mellett a környezettel való interakciókat is figyelembe kell venni. Két dimenzionális konstruktum, amely egyfelöl a nehéz körülmények, helyzetek expozíciójára, másrészről ezeknek a nehéz helyzeteknek a lehetséges pozitív kimeneteleire összpontosít [7].

A reziliencia fogalmának gyökerei pszichológiai aspektusból a megküzdés fogalmára, biológiai szempontból pedig a stressz fiziológiai tüneteinek vizsgálatára vezethetők vissza.

Ahogyan említettem a reziliencia arra a folyamatra vonatkozik, amikor az egyén kedvezőtlen, veszélyeztető körülmények ellenére is pozitív adaptációt mutat [8]. A reziliencia kutatások egyik célja így azon folyamatok feltárása, amelyek kedvező kimenetelekhez vezetnek. Maga a reziliencia fogalma két alapvető kritériumhoz kapcsolódik:

- a rizikó fogalmának a meghatározásához, hiszen csak meglévő rizikó esetén beszélhetünk rezilienciáról,

- másrészt annak a definiálásához, hogy mit tekintünk kedvező kimenetelnek.

Masten, Best és Garmezy a reziliencia jelenségének három típusát különítik el:

- magas rizikójú háttér ellenére kedvezőbb kimenetelt mutató egyének (fejlődéspszichológia területén),
- stresszes tapasztalatok mellett kialakuló pozitív alkalmazkodás és kompetencia,

- traumából való felépülés (például katasztrófák, háborús helyzeteket vizsgáló kutatások esetében).

A pszichológia területén reziliencia - kutatások elsőként a fejlődéslélektan területén bontakoztak ki, később egyre inkább elterjedtek azok a vizsgálódások, ahol traumatikus vagy extrém események hatásait vizsgálták felnőttkorban is. Azaz milyen mértékben, patológiával vagy anélkül, képes felépülni az egyén egy traumatikus helyzet után.

\section{A reziliencia és felnőttkori pszichotrauma kapcsolata mint új kutatási irány}

Napjainkban egyre több kutatás foglalkozik a traumatikus eseményeket követő gyógyulási folyamattal. Míg korábban sokkal inkább a patológiát helyezték elötérbe és a rizikófaktorok, a vulnerabilitás kutatása kapott hangsúlyt, addig mostanában egyre nagyobb figyelmet kap az a jelenség, hogy egyesek súlyos traumát követően sem betegednek meg, nem alakul ki náluk sem a poszttraumás stresszbetegség, sem más mentális betegség, és viszonylag rövid időn belül képesek egészséges életvezetésre visszatérni.

Számos elmélet és tanulmány ismerteti a reziliencia traumával összefüggő koncepcióját, azonban mindmáig nem született egységes definíció. Jelenleg két megközelítés jellemző: az egyik Bonanno-é, amely egy szükebb definíció, a másik pedig egy szélesebb, tágabb értelmezésü. Bonanno [9] egyszeri, rövid ideig tartó trauma hatását veszi figyelembe. A rugalmas egyén ennek során átélhet rövid idejű érzelmi, fizikai diszregulációt, 
változásokat, de ezt követően képes folytatni és teljesíteni a személyes és szociális feladatait, és akár pozitív érzelmeket megélni. A definíció hátránya azonban az, hogy elmosódik a különbség a gyógyulás és a reziliencia fogalma között, másrészt a definícióban csak egyetlen, elszigetelt traumatikus eseményre összpontosít, és nem veszi figyelembe a krónikus stressz, többszörös trauma hatását. Ő inkább statikus és vonás jellegü entitásnak feltételezi, mintsem dinamikus folyamatnak, amely időről időre alakulhat és a körülmények, valamint más külső, belső változók is szerepet játszhatnak alakulásában. Bonanno definíciójával ellentétben sok kutató önálló, egymástól jól elhatárolt konstrukcióként kezeli a gyógyulás és a reziliencia fogalmát. E megfogalmazások közül egyesek az ellenállóképességet egy dinamikus és kontextusfüggő konstrukcióként írják le, amely jellemezhető akár a stressz indukálta tünetek hiányával, de akár e tünetek oldódásának (gyógyulás) természetes folyamatával is [10]. További különbségek abból is adódnak, hogy ki milyen forrásokból származtatja a pszichológiai ellenállóképességet. Néhány kutató egyénen belüli forrásokat fogalmaz meg, mások viszont úgy vélik, hogy inkább többféle és nemcsak egyénen belüli forrásokból alakulhat ki a reziliencia. Így figyelembe kell venni akár pszichológiai és diszpozicionális tulajdonságokat, valamint a szociális kontextust is (pl. családi és egyéb külső támogató hálózat).

Âltalában mindegyik megközelítés összefüggésbe hozza a reziliencia fogalmát más hasonló és átfedő konstrukciókkal, így a „szívósság” (hardiness), „erősödés” (thriving) és a „poszttraumatikus fejlődés" (posttraumatic growth) fogalmaival. A szívósság, mint személyiségvonás az extrém stressz elhárításában segít. Három dimenziót ölel fel: a képességet, hogy beazonosítsuk életünk jelentőségteljes céljait; azt a hiedelmet, hogy az emberek képesek környezetük és az események kimenetelének megváltoztatására; és a hitet abban, hogy az emberek képesek mind a negatív, mind a pozitív tapasztalataikból tanulni. A szívós egyén magabiztosabb, a coping készségek hatékonyabb tárával rendelkezik és a szociális támogatást is képes a hasznára fordítani [11].

$\mathrm{Az}$ erősödés csökkenti a stresszorra adott fokozott reaktivitást, gyorsítja a felépülést és a stresszort, traumát követően egy magasabb szintü funkcionálást eredményez. Így javulást eredményezhet az egészségi állapotban, a pszichológiai jól-lét kialakulását fokozhatja, új készségek megszerzését, a magabiztosság érzését és a szociális kapcsolatokat is fejlesztheti. Mindezek ellenére bizonytalan maradt, hogy a pszichológiai erősödés egydimenziós vagy többdimenziós konstruktum-e és nem bizonyított, hogy ez a fogalom miben és hogyan különbözik a szívósság és a poszttraumatikus fejlődés koncepcióitól, valamint a coping folyamatokkal való kapcsolata szintén kevésbé tisztázott.

A poszttraumatikus fejlődés fogalmát sok kutató vizsgálta. A koncepció a traumát vagy bármilyen élethelyzeti nehézséget követő személyes fejlődéssel, növekedéssel kapcsolatos. Az erősödés fogalmához hasonló, a rezilienciával ellentétben viszont utal arra az aspektusra, hogy a traumát megelőző működési szinthez képest a traumát követő időszakban egy magasabb szintű funkcionálás valósul meg, valamint átalakulnak, pozitívvá válnak az egyén önmagával, másokkal, a világgal kapcsolatos jelentős sémái. Ugyanakkor ennek a poszttraumatikus növekedésnek van egy illuzórikus, ún. önámításos változata is, például a személy a trauma "tagadása” következében 
kezdi el az adaptív funkcionálást [12].

A pozitív érzelmek alapvető fontosságú szerepét a reziliens személyiségjegyben több kutatás is alátámasztotta: a tapasztalatok azt mutatják, hogy a reziliens emberek több pozitív érzelemről számolnak be [13].

A reziliens személyeknél a pozitív érzelmek hatékonyan csökkentik a stressz megélését és segítik a pszichológiai erőforrások aktivizálását olyan általános és megrázó katasztrófahelyzetekben is, mint pl. a New Yorkban 2001. szeptember 11-én bekövetkezett terroristatámadás. A reziliens személyek több pozitív érzelmet élnek meg, amelyek jelentőségét a rehabilitációban és a betegségekből való felépülésénél szerzett tapasztalatok is alátámasztják[14].

A koherenciaérzet fogalma és a reziliencia számos ponton kapcsolódik egymáshoz. Hart, Wilson és Hittner arra jutottak, hogy a magas koherenciaérzettel rendelkező emberek több pozitív érzelmet élnek meg és kevesebb betegségről számolnak be, amelyet a szerzők egyúttal a reziliens személyek jellemzőjének tekintenek [15].

Láthatjuk, hogy mennyire kialakulatlan még a reziliencia definíciója, illetve mennyire összetett. Számos más fogalom is tartamaz hasonló aspektusokat, ugyanakkor hiányzik a konszenzus a reziliencia és többi konstruktum közötti kapcsolatról.

A modellek egy része a reziliencia konstruktumát, azaz a különböző meghatározó faktorokat, azok egymásra hatását elemzi, személyiség, vagy kognitív, vagy biológiai orientáció jellemzi őket, és a folyamat pozitív kimenetele a poszttraumatikus fejlődés vagy erősödés, a gyógyulás vagy a környezethez való alkalmazkodás, esetleg a túlélés lesz. Más modellek nem a reziliencia, hanem az alkalmazkodás, a poszttraumatikus fejlődés, szívósság fogalmából indulnak ki és a folyamat eredménye a reziliencia kialakulása lesz. A legtöbb esetben azért elmondhatjuk, hogy a teóriák, modellek hangsúlyozzák az extrém helyzetek, traumák, súlyos élethelyzeti nehézségek jelenlétét, amelyekkel szembe kell néznie az egyénnek. Rendelkezésére állnak a vulnerabilitásért felelős rizikófaktorok és ezzel szemben rezilienciáért felelős protektív faktorok. A végeredmény pedig:

- vagy egy homeosztatikus/egyensúlyi állapot kialakulása, a reziliencia, azaz a korábbi szinten való működés viszszatérése,

- vagy egy magasabb szinten való funkcionálás, azaz a poszttraumatikus fejlődés, erősödés,

- vagy a diszfunkciók, mentális betegségek kialakulása, azaz egy alacsonyabb szinten történő működésmód.

A 2013-as International Society for Traumatic Stress Studies (ISTSS) konferenciáján megrendezésre kerülő kerekasztal beszélgetésen, Dr. Steven Southwick (elnök) és több féle diszciplína képviselője (George Bonnano, Ann Masten, Catherine Panter-Brick, Rachel Yehuda) vitatta meg a reziliencia kutatás aktuális kérdéseit. Ezek a következők voltak:

a) hogyan definiáljuk a rezilienciát,

b) melyek a legfontosabb meghatározói,

c) hogyan szolgálhatják a legújabb technológiák a reziliencia tudományát,

d) melyek a leghatékonyabb módjai a reziliencia elősegítésének?

A résztvevők rezilienciáról alkotott fogalma kissé eltért egymástól, mind a 


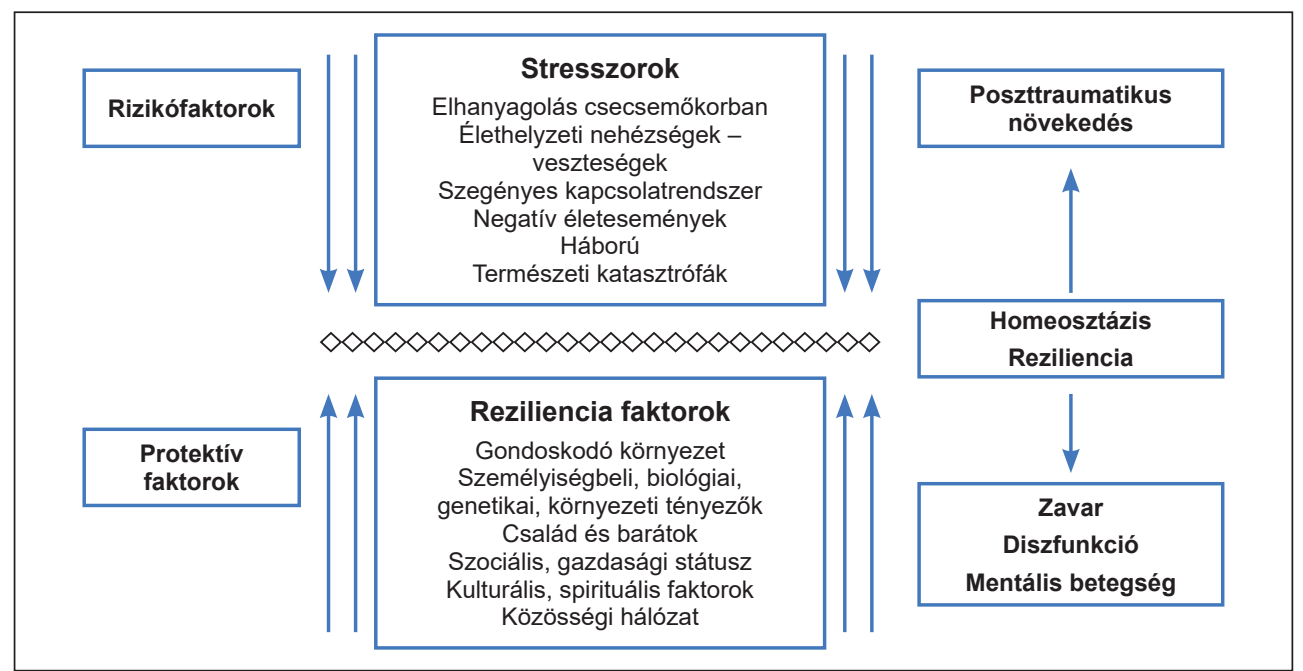

2. ábra. Rezilienciát fokozó és csökkentö faktorok

Forrás: Herrman, H. et al.: What is resilience? The Canadian Journal of Psychiatry, 2011; 56(5):258-265.

mai napig nem sikerült teljesen egységes koncepcióként megfogalmazni a reziliencia jelenségét. A legtöbb definícióban azért mégis sikerült egy olyan koncepciót meghatározni, ami egészséges, adaptív, integrált és pozitív funkcióra enged következtetni, amely az idövel nyilvánul meg megrázkódtatásokat követően. A résztvevők megegyeztek abban, hogy a reziliencia egy összetett konstruktum, így annak meghatározása más lehet az egyén, a család, a szervezet, a társadalom vagy akár a kultúra szintjén. A reziliencia meghatározói kapcsán szintén konszenzus volt a szakértők között, abban hogy az empirikus vizsgálatokat több szintről érdemes megközelíteni, így beszélhetünk genetikai, epigenetikai, fejlődéslélektani, demográfiai, kulturális, gazdasági és szociális változókról. Az empirikus vizsgálatok előmozdíthatják a reziliencia fejlesztését célzó erőfeszítéseket az egyén, a család, a szerveztek, a társadalom és a kultúrák szintjén is [16].

\section{Összegzés}

A reziliencia széleskörü fogalom, amely szélsőséges változások vagy fenyegetettség esetén is megvalósuló pozitív alkalmazkodási képességet jelent. Ez a vészrugalmasság dinamikus, hiszen ugyanaz az egyén viselkedhet egyszer maladaptív, máskor pedig reziliens módon. Két magyarázó modell létezik, hogy megértsük ezeket az ellentmondó viselkedésekett. Az egyik a kiegyenlítö modell, amely szerint a rizikófaktorok semlegesítésével, ellensúlyozásával tud az egyén közvetlen, pozitív hatást elérni. Ez előnyökről, erőforrásokról, protektív faktorokról beszél, és figyelmen kívül hagyja a károsító hatás erősségét. A másik, a védőfaktor modell akkor bír nagyobb erővel, amikor a károsító ágens erősnek mutatkozik. Ez a modell alacsony mértékủ kihívás esetén nem érvényes. $\mathrm{E}$ két modell segít abban, hogy a reziliens viselkedés különböző mintázatait megértsük [17]. Masten és Wright négy, egymástól elhatárolható vészrugalmasság mintát azonosított: 
- Ellenállás: ésszerü, kiegyensúlyozott, adaptív viselkedésminta, amelyet azok a gyermekek mutatnak, akik hátrányos körülmények ellenére a korukra jellemző fejlődési feladataikat sikerrel megoldották.

- Kilábalás: az a viselkedésmintázat, amikor az egyén adaptív viselkedésformája egy csapás eredményeként átmenetileg megszünik, majd az illető újból visszatér a megfelelő szintre. Ez a minta jellemzö a folyamatos stressznek való kitettség vagy hirtelen katasztrófák esetén.

- Normalízáció: akkor valósul meg, ha egy gyermek születésétől fogva egy ártalmas környezetben él és ebből kiszabadul, jobb feltételek közé kerül.

- Átalakulás: a vészrugalmas viselkedés egy olyan fajtája, amikor is egy csapás következtében az egyén adaptív funkciói javulnak, ez a poszttraumatikus növekedés.

A reziliens viselkedés e négy mintázata az emberi fejlődési szakaszok mindegyikének feladatait segít megoldani, a rezilienciára tehát egy élethosszon tartó védőfaktorként számíthatunk.

A reziliencia-kutatások harmadik évtizedében megfogalmazódott kérdések megválaszolása átvezetett a rezilienciakutatások ma érvényes negyedik szakaszába. Korunk reziliencia-kutatói már, mint integrált alkalmazkodó rendszerként beszélnek a vészrugalmasságról. A következő tíz integrált területet különítették el a kutatók, amelyeknek leginkább szerepe van a reziliencia konstruktumának kialakításában:

- egészség és a stressz-rendszer (allosztázis, a normál immun- és HPA funkciók)
- információs folyamatok és problémamegoldó rendszer (normál kognitív fejlődés, IQ)

- kötődési kapcsolatok szülőkkel, barátokkal és másokkal (biztonságos kötődés)

- önszabályozás, önirányítás, gátlórendszer

- irányító- és jutalmazórendszer

- spirituális, vallásrendszer

- család rendszere (zárt kapcsolat a szülőkkel, szülők által támogatott tanulás, nyugtató rituálék és rutin)

- egyenrangú társas rendszerek

- iskola (alkalom a tanulásra, kapcsolatot támogató felnőttekkel és társakkal, stb.) széles közösség és kulturális közeg.

\section{Irodalom}

[1] Taylor, M. K., Markham, A. E., Reis, J. P. et al.: Physical fitness influences stress reactions to extreme military training. Military Medicine, 2008; 173(8): 738-742.

[2] Békés Vera: A reziliencia-jelenség, avagy az ökologizálódó tudományok tanulságai egy ökologizált episztemológia számára. In: Forrai G., Margitay T. (szerk): Tudomány és történet. Tanulmánykötet Fehér Márta tiszteletére. Budapest, Typotex, 2002, 215-228.

[3] Garmezy, N., Masten, A. S., Tellegen, A.: The study of stress and Competenx in children: A building block for developmental psychopathology. Child Development, 1984, 55: 97-111.

[4] Rutter, M.: Resilience, competence, and coping. Child abuse and neglect, 2007, 31: 205-209. DOI: 10.1016/j.chiabu.2007.02.001

[5] Masten, A. S.: Resilience in developing systems: Progress and promise as the fourth wave rises. Development and Psychopathology. 2007, 12: 857-885.

DOI: $10.1017 /$ S0954579407000442

[6] Gordon, K. A.: The self-concept and motivational patterns of resilient African American high school students. Journal of Black Psychology, 1995, 21: 239-255. DOI: abs/10.1177/00957984950213003 
[7] Luthar, S.S., Cicchetti D., Becker, B.: The construct of resilience. The critical evaluation and guidelines for future works. Child Development, 2000; 71(3): 543-562. DOI: $10.1111 / 1467-8624.00164$

[8] Masten, A., Best, K., Garmezy, N.: Resilience and development: contribution from the sudy of children who overcome adversity. Development and Psychopathology, 1990, 2: 425-444.

DOI: $10.1017 / S 0954579400005812$

[9] Bonanno, G. A.: Loss, trauma and human resilience: Have we underestimated the human capacity to thrive after extremly aversive events? American Psychologist, 2004, 59: 20 28.

DOI: 10.1037/0003-066X.59.1.20

[10] Luthar, S. S., Cicchetti, D.: The construct of resilience: Implications for interventions and social policies. Development and Psychopathology, 2000, 12: 857-885.

[11] Kobasa, S. C., Maddi, S. R., Kahn, S.: Hardiness and health: A prospective study. Journal of Personality and Social psychology, 1982, 42:168-177.

[12] Carver, C. S.: Resilience and thriving: Issues, models, and linkages. Journal of Social Issues, 1988, 54: 245-266.

DOI: 10.1111/j.1540-4560.1998.tb01217.x

[13] Ong, A. D., Bergeman, C. S., Bisconti, T. L. Wallace, K:. Psychological resilience, positive emotions, and successful adaptation to stress in later life. Journal of Personality and Social Psychology, 2006, 91:730-749.

DOI: $10.1037 / 0022-3514.91 .4 .730$

[14] Fredrickson, B. L., Tugade, M. M., Waugh, C. E., Larkin, G. R.: What good are positive emotions in crisis? A prospective study of resilience and emotions following the terrorist attacks on the United States on September 11th, 2001. Journal of Personality and Social Psychology, 2003, 84: 365-376. DOI: 10.1037/0022-3514.84.2.365

[15] Hart, K. E., Wilson, T. L., Hittner, J. B.: A psychosocial resilience model to account for medical well-being in relation to sence of coherence. J. Health Psychol., 2006, 11(6): 857-862.

DOI: $10.1177 / 1359105306069082$
[16] Southwick, S. M., George A. Bonanno, G. A., Masten, A. S., Panter-Brick, C., Yehuda, R.: Resilience definitions, theory and challanges: interdisciplinary persepctives. European Journal of Psychotraumatology, 2014, 5: 25338. http://dx.doi.org/10.3402/ejpt.v5.25338 DOI: $10.1177 / 1359105306069082$

[17] Masten, A. S., Wright, M. O’D.: Resilience over lifespan: Developmental perspectives on resistance, recovery, and transformation. In: Reich, J. W., Zautra, A. J., Hall, J. S. (Eds): Handbook of adult resilience. New York, Guilford Press, 2009, 213-237.

\section{Lt.Col. Nóra Urbán, \\ Col. (ret.) L. Kovács MD, PhD}

\section{Psychological resilience, the integrated adaptation system}

Following the terrorist attack of September 11th, 2001 the facts, data and publications by the American Psychological Association are laying more emphasis on the role of flexible resistance or psychological resilience regarding the tragic events. Most persons have capabilities that enable coping with even extremely high levels of stress. Psychological resilience is an adaptational process which helps manage difficult life situations, disasters, tragedies, traumas; the individuals are able to efficiently cope with the symptoms of distress caused by the trauma. International resilience research is increasing regarding childhood and adult life (multiple) traumas as well as traumas in connection with extreme stress situations in the defense sector.

Keywords: psychological resilience, psycho trauma, post traumatic stress disease (PTSD)

Urbán Nóra alez. 1134 Budapest, Róbert Károly krt. 44. 